\title{
"What the great Alexander and the famous Julius Caesar wanted so much to see". A commemoration of the fourth centenary of the Blue Nile Sources discovery by the Spanish Jesuit Pedro Páez Xaramillo (April 21th, 1618)
}

\author{
Víctor M. Fernández \\ Dpto. Prehistoria, Historia Antigua y Arqueología, Universidad Complutense, Madrid \\ e-mail: victormf@ucm.es \\ ORCID iD http://orcid.org/0000-0002-7488-9370
}

Submitted: 28 August 2018. Accepted: 07 January 2019

\begin{abstract}
On April 21, 1618 Pedro Páez visited the small spring where the waters of the Blue Nile rise before passing through Lake Tana. The site had been seen before by the military leader of the group of Ethio-Portuguese descendants of the Portuguese soldiers who had helped the Christian kingdom in the wars of 1541-1543, who passed the news to the missionaries shortly before 1607. In both cases the Ethiopian kings, Särsä Dengel and Susenyos, took them to the sources, showing that the local population had a clear knowledge of the river course. Páez was the first European who described all its characteristics, occupying a complete chapter of his "History of Ethiopia". Although this book was not published until the 20th century, the manuscript was copied and the information was incorporated into the global knowledge before the end of the 17th century, through the works of the German Jesuit Athanasius Kircher and the maps of the Venetian geographer, Vincenzo Coronelli. In this way, a problem that had intrigued travellers, geographers and historians since antiquity was solved. The next European who visited the place was the Scottish James Bruce in 1770, and the sources in Lake Victoria of the other large arm of the river, the White Nile, were not discovered until two and a half centuries later, with the travels of the English John Hanning Speke in 1858-1862.
\end{abstract}

KEYWORDS: Nile river; Ethiopia; Geography; Mapping; Jesuit missions.

Citation / Cómo citar este artículo: Fernández, Víctor M. (2019) ““'What the great Alexander and the famous Julius Caesar wanted so much to see". A commemoration of the fourth centenary of the Blue Nile Sources discovery by the Spanish Jesuit Pedro Páez Xaramillo (April 21th, 1618)" Culture \& History Digital Journal, 8 (1): e012. https://doi.org/10.3989/chdj.2019.012

RESUMEN: “Lo que el gran Alejandro y el famoso Julio César desearon tanto ver". Una conmemoración del cuarto centenario del descubrimiento de las fuentes del Nilo Azul por el jesuita español Pedro Páez Xaramillo (12 de abril de 1618).- El 21 de abril de 1618 Pedro Páez visitó el pequeño manantial de donde surgen las aguas del Nilo Azul antes de pasar por el lago Tana. El sitio había sido visto antes por el jefe militar del grupo de luso-etíopes descendientes de los soldados portugueses que habían ayudado al reino cristiano en las guerras de 1541-1543, quien pasó la noticia a los misioneros poco antes de 1607. En ambos casos fueron los reyes etíopes, Särsä Dengel y Susenyos, los que les llevaron a las fuentes, demostrando que la población local tenía un claro conocimiento del curso del río. Páez fue el primer europeo que describió todas sus características, ocupando un capítulo completo de su "Historia de Etiopía". Aunque este libro no se publicó hasta el siglo XX, el manuscrito fue copiado y la información se incorporó al conocimiento global antes del final del siglo XVII, a través de las obras del jesuita alemán Athanasius Kircher y los mapas del geógrafo veneciano Vincenzo Coronelli. De esta forma se resolvió un problema que había intrigado a viajeros, geógrafos e historiadores desde la Antigüedad. El siguiente europeo que visitó el lugar fue el escocés James Bruce en 1770, y las fuentes en el lago Victoria del otro gran brazo del río, el Nilo Blanco, no se descubrieron hasta dos siglos y medio más tarde, con los viajes del inglés John Hanning Speke en 1858-1862.

PALABRAS CLAVE: Río Nilo; Etiopía; Geografía; Cartografía; Misiones jesuitas.

Copyright: (C) 2019 CSIC. This is an open-access article distributed under the terms of the Creative Commons Attribution 4.0 International (CC BY 4.0) License. 


\section{INTRODUCTION}

Pedro Páez Xaramillo (1564-1622) was born in the village of Olmeda de las Fuentes, then belonging to the diocese of Toledo and today located in the province of Madrid (Figure 1). Being twenty years old he was admitted to the Society of Jesus to study at its school in Belmonte (Cuenca) and in 1588 he was sent to India. After a year studying theology in Goa, he was sent with another Jesuit missionary and great traveller, the Catalan Antonio de Montserrat, to Ethiopia. This ancient Christian kingdom, known since the Middle Ages as the country of Prester John, had been visited by the Portuguese (as emissaries first and later soldiers under the command of Christovão da Gama, who between 1541 and 1543 helped the Christians to win a hard and long war against the Muslims of the Somali region), and there was a small Jesuit mission in its northern region (Fremona in Tigray) since the 1560's. During the sea voyage, Montserrat and Páez were captured by an Arab ship and ended up imprisoned by the Ottomans in Sana'a (Yemen) until Indian merchants associated with the Jesuits paid their ransom in 1596 (Caraman, 1985, Gonzalez, 1990, Reverte, 2001, Bishop, 2002, Cohen, 2009, Martínez, 2010a, 2015, Páez, 2009, 2014).

In 1603 Páez tried the crossing again, travelling alone on an Indian ship and arriving on May $15^{\text {th }}$ in Fremona. In that place, where today one can still see the impressive fortification with circular towers that the missionaries built on a high hill, there were no Jesuits left of the small group that had been led by the first Catholic patriarch of Ethiopia, the Spanish Andrés de Oviedo (1518-1577). Those who did welcome Páez were the members of the Ethio-Portuguese mestizo community, descendants of the soldiers of Christovão da Gama who had preserved their fathers' Catholic faith and whose spiritual service appeared as the first and main purpose of the Jesuit endeavour.

With the help of other fathers who arrived shortly after, Páez served as superior of the mission until 1618 and soon contacted the Ethiopian kings, first Zä Dengel and Yaeqob, and then Susenyos, who reigned for a longer time (1607-1632) and with whom he came to enjoy a great friendship. Helped by one of the king's halfbrothers, Seela Krestos, he gradually convinced the royal environment of the superiority of the Roman Catholic version of Christianity over the monophysite Orthodoxy of the Ethiopians, who had remained faithful to the Coptic Egyptian church of Alexandria, separated from the Roman line since the Council of Chalcedon in 451. At the same time, he undertook architectural works that were novel in Ethiopia at the time, consisting of a palace for the king in Gorgora Nova and two churches, in Gorgora Velha and AzäzoGännätä Iyäsus, both places north of Lake Tana in the central area of the Abyssinian kingdom. Although still built without mortar (which is why they have not been preserved until our days), not introduced by the missionaries until 1624, the buildings had a square plan in European style and the palace was two stories high.

But the most important activity of Páez, from the current perspective, was his great work of observer and

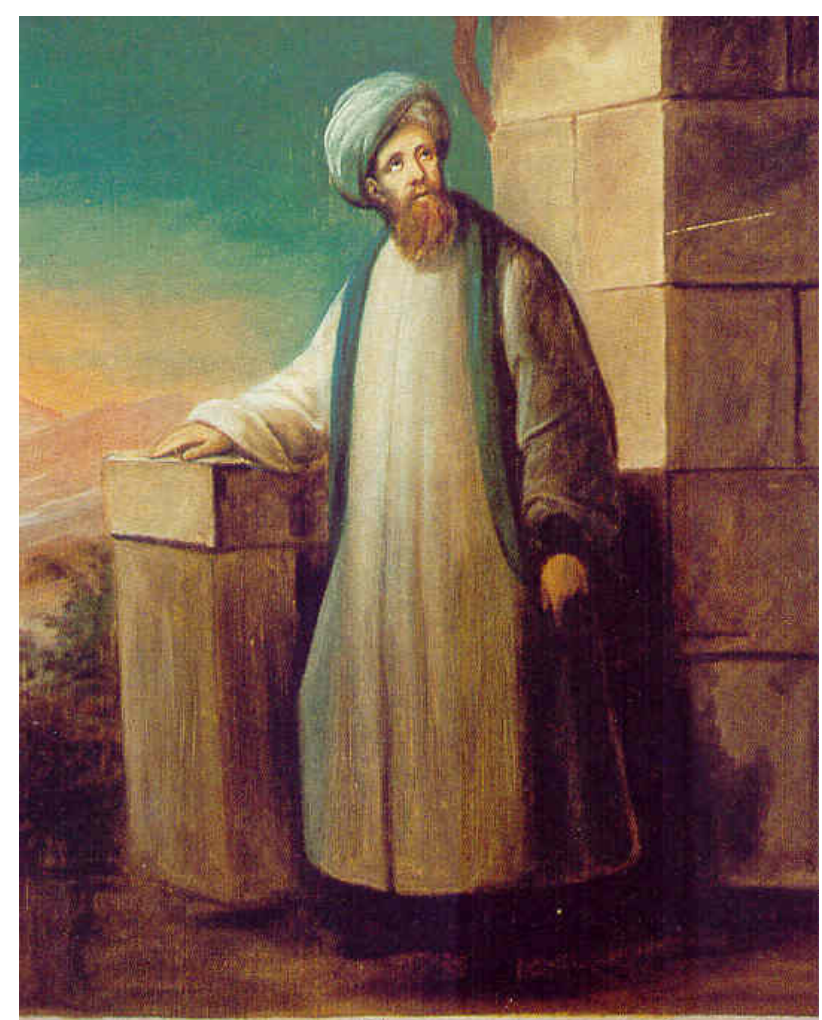

'PRDRO PARZ, ESPA TOL, DH LA COMPAÑIA IDE J SIS. IDESPIIES DE 6 A TOS IDI CAITIVERIO Y IDI 20 IDE IATIGAS EN RSTE TRAGW. EN BIIOPIA. RI GONCHLIO CON LA I GL. ROM. AL PRESTE.A. SI IM

Figure 1. Fictional representation of Pedro Páez at the Loyola sanctuary (Guipúzcoa).

compiler of information, which he transmitted in written form in a series of long letters to his superiors, family and friends, and especially in his magnum opus, Historia de Ethiopia, which he wrote between 1615 and 1621 (Figure 2). To complete it, in addition to collecting information personally, he translated a series of important ancient texts including the religious and administrative chronicles of the royalty, written in the local language ( $g e ' e z$ ). With them he got a very accurate description of the distant and unknown country, surpassing the information written by the Portuguese chaplain Francisco Alvares after his visit in 1520 and published in Lisbon in 1540 (Beckingham and Huntingford, 1961). Although the Historia was not published in its entirety until 1905-1906, within the series of the Jesuit authors on Ethiopia compiled by Camilo Beccari (RASO, vols. II and III), the text was used by other Jesuit authors (Almeida, Telles, Lobo, etc.) and Athanasius Kircher and other authors and cartographers, such as the Venetian Vincenzo Coronelli, popularised its data before the end of the 17 th century.

The traditional historiography on the Jesuit period in Ethiopia is divided into two main currents, positive and negative. As expected, Jesuit historians and Catholics in general pay attention to the modernizing work that the missio- 


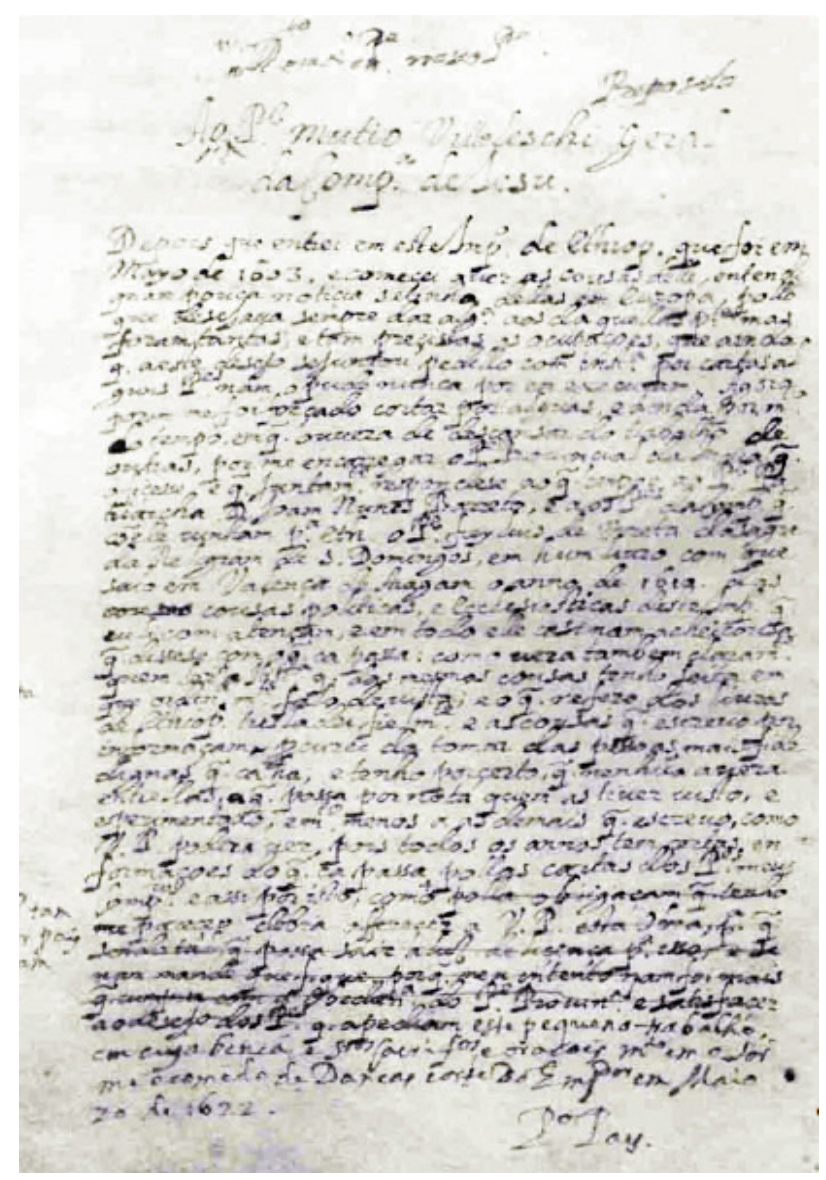

FIGURE 2. First page of the manuscript of Historia de Ethiopia (RASO II: pl. I). naries carried out, introducing European ideas and techniques in a still very backward region, in addition to conducting very advanced studies for their time on that unknown part of Africa, long before the first European explorers arrived during the 19th century (e.g. Caraman, 1985, González, 1998, Reverte, 2001; Bishop, 2002). Most Anglo-Saxon authors, together with contemporary Ethiopian historians, have presented almost to this day a rather negative view, especially because of the religious and civil conflicts caused by the contact (e.g. Pankhurst, S. 1955, Crummey, 2000, Pankhurst, R., 1998, Merid, 1998).

Certainly, although Pedro Páez and his successor António Fernandes were very cautious in their evangelizing work, fearing a contrary reaction from the local population and clergy, the optimism that followed the victory of the Catholic side over the Orthodox at the Battle of Sädda in 1617 and then the arrival of the new Ethiopian patriarch, the Portuguese theologian Afonso Mendes, in 1624 provoked a much more intransigent attitude by the Catholics. They opposed strictly to customs dictated by the Orthodox Church, some of little doctrinal importance, such as circumcision, the observance of the Sabbath or the marriage of the priests, as well as declaring the latter heretical when they had not been re-ordained by Patriarch Mendes. This provoked a strong reaction in the religious-monastic and popular levels, with bloody confrontations that caused Susenyos to have to retract his condemnation of orthodoxy shortly before his abdication and death, and that his successor Fasilädäs (r. 16321667) (Figure 3) declare illegal the Roman faith and expelled the Jesuits from all the Abyssinian territory in 1633. As a reaction, Ethiopia remained closed to the Western world until about two centuries later during the European colonial expansion of the nineteenth century.

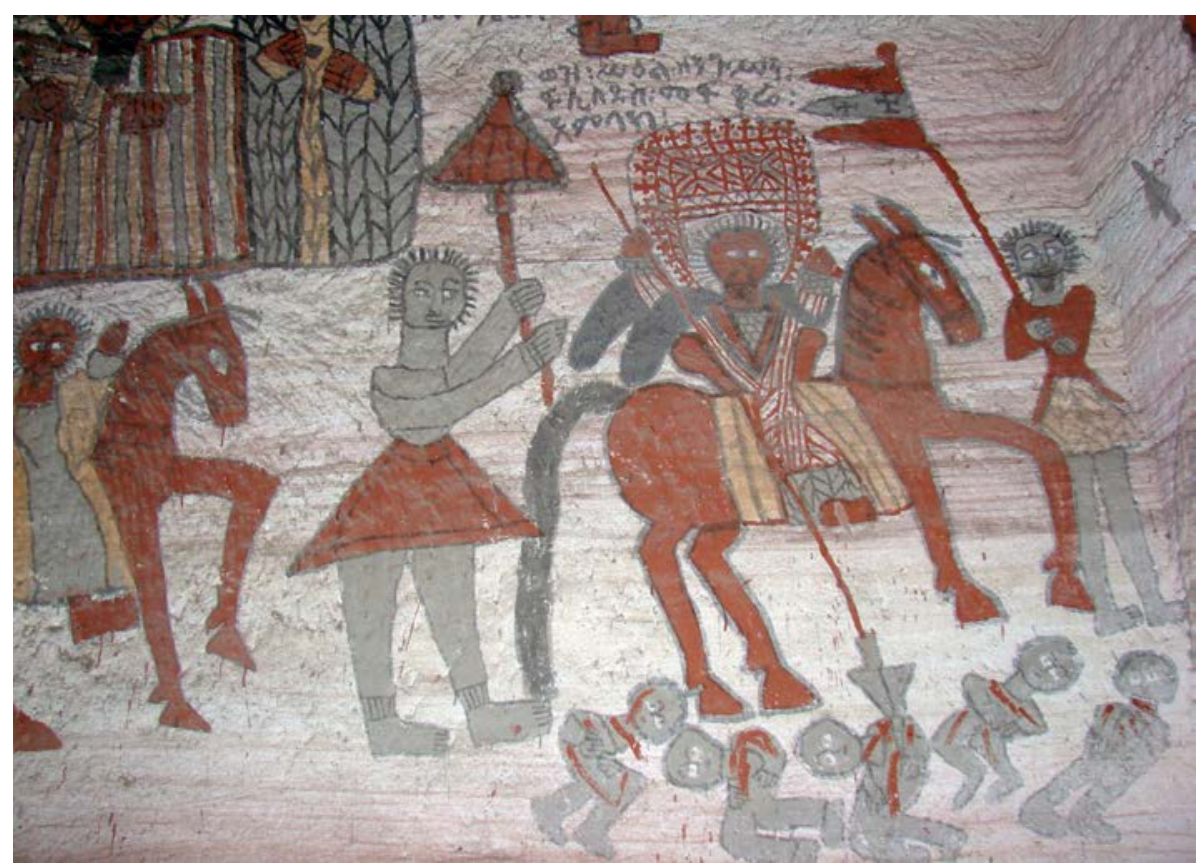

FIGURE 3. Representation of king Fasilädäs in the church of Maaqudi (Gheralta, Tigray). The text over the king reads "Our king Fasilädäs, lover of God". Author's photograph, Dec. 2008. 
In short, the Jesuit legacy can be considered positive by the technical advances that were introduced, especially in architecture, and the reinforcement of the monarchy, but also negative by the resulting isolation and at the doctrinal level by the subsequent theological discussions on the human-divine nature of Christ, who caused deep divisions during the following centuries, even reaching the armed conflict, among the Orthodox clergy and monks.

\section{THE JESUIT MISSIONARY SITES IN ETHIOPIA}

In the area of the Abyssinian kingdom, the Jesuits came to project and implement a total of 19 missions, which clearly shows that they believed the conversion of the country to Catholicism was already an accomplished fact. Of these missions, three were in the northern region of Tigray and 16 were closer to the nucleus of the kingdom, around Lake Tana. Physical (architectural) remains have been found, and therefore the exact location is known, of nine of them, where they erected or started to build sophisticated structures, that included stone and mortar churches, residences, schools, water conductions, large cisterns, bulwarks and towers. On the remaining 10 missions there is some idea of where they might have been (usually by very similar current place names) but remains of the constructions have not been preserved (or have not yet been found). The latter can be explained because at first the missionaries built their houses and churches using the local technology with vegetal materials or stone without mortar, from which very few traces are left with the passage of time (Ramos \& Boavida, 2004; Fernández, 2013; Fernández et al., 2017).

In several missions, data are known indicating that the Jesuits chose places with some religious significance to settle down, trying to connect the religious fervour of the Orthodox religion with the new Roman faith. From 1624, according to father Almeida in his documented history (RASO, VI: 390-391), the arrival of an Indian technician who knew how to make lime mortar and the discovery of nearby calcitic sandstone outcrops (in an eminently volcanic region where that type of rock is quite rare) allowed building more durable buildings. The first ones that were made with the new technique were a small palace for the king in Azäzo-Gännätä Iyäsus, near which after the expulsion would be founded the new kingdom capital, Gondär, and the mission church of Särka, south of Lake Tana in the Gojjam region. Soon other churches were made with stone and mortar (Azäzo, Gorgora Nova, Dänqäz, Märtulä Maryam, Leggä Negus, Qwälläla ...) and an important residence for Patriarch Mendes was erected in Däbsan. The Jesuit temples followed in general the norm, preferred by the Company, of a single nave so that the faithful could attend and see the celebrations without any intermediate obstacle.

Since the presence of mortar is known in a few constructions from the Aksumite period of Ethiopia (first millennium $\mathrm{BC}$ - first millennium AD), some researchers have played down the importance of its introduction by the Jesuits (e.g. Merid, 1984), but the clear fact is that there are not known constructions with that technique in the country from those few ancient examples until the seventeenth century.
As a novel result of the recent archaeological research by the Complutense University in the Ethiopian mission sites, financed by the Ministry of Culture (Instituto del Patrimonio Cultural de España) and the Ministry of Foreign Affairs (AECID), and directed between 2006 and 2018 by the author of this paper, which consisted of surveying all known sites and excavating in Azäzo, Gorgora Nova and Särka (Fernández et al., 2017), it has been shown that the missionaries built sophisticated underground water conducts, linked to latrines and toilets, which agrees with the importance that the Company gave to cleanliness and hygiene since its foundation, but which are not mentioned in the texts written by the missionaries. Another discovery was the way in which the orthodox re-signified the Catholic buildings after the expulsion, to make them acceptable by the orthodox norm: on several occasions they built new walls that converted the open room of the Catholic churches into the tripartite space characteristic of oriental churches, with a closed "sancta sanctorum" interior (mäqdäs in the local language) that only priests can access. It is curious that sewage pipes, latrines and toilets were not reused, but on the contrary destroyed or intentionally blocked off, as if the Orthodox identified these new European technologies with the Roman Catholic heresy.

There is general agreement about the Jesuit influence in the reinforcement of the Abyssinian monarchy. Before the missions, the kings changed residence frequently (it was a peripatetic monarchy) erecting large camps with perishable materials, but as soon as the missionaries left the country, the new king Fasilädäs chose Gondär as a fixed capital. He also built an impressive four-story palace of square plan with circular towers in its corners (one of the current tourist attractions and a kind of symbol of Ethiopia) that undoubtedly sought to reinforce his image of authority before his subjects and above all in the face of the rebellious regional nobility. The origin and models of this architecture, which was later completed by his successors while Gondär remained the capital until the mid-18th century, has been much discussed, with most "post-colonial" local and Anglophone historians favouring an oriental origin (India, Ottoman Empire), rather than a European influence. However, the great resemblance between these buildings and the palace and fortifications erected very close by the missionaries (in Azäzo, only a few kilometres from Gondär), makes it difficult not to think that their inspiration (together with the permanence in the country of the Indian technicians who had accompanied them from Goa and Diu) was crucial in the formation of Gondärine architecture.

\section{FIRST IDEAS AND MYTHS ABOUT THE NILE RIVER}

Apart from the well-known phrase that attributed a special "holiness" to the inhabitants of Ethiopia (who "extend their hands to God", Psalms, 68:31), the other famous reference in the Bible about that region says that from Earthly Paradise came four rivers, Tigris, Euphrates, Pishon and Gihon, the latter flowing "around the whole land of Kush 
[another ancient name of Sudan and Ethiopia]" (Genesis, 2: 13). This idea lasted in Europe from Antiquity to the Middle Ages and later, linked to the fantasy that the Nile had its sources in the Garden of Eden. (It even continues today in a certain way: the network of state hotels in Ethiopia receives the Biblical name of the river, although actually most of them are far from being paradisiacal ...)

Since ancient times the origin of the Nile was a great unknown that aroused the curiosity of many people. How was it possible that that big amount of water emerged in Egypt from a huge desert where it never rained? (Figure 4). The solution to the problem demanded to be able to cross that desert, something that was not possible until much later. The Greek "father of history", Herodotus, was informed in the fifth century BC during his visit to Egypt that the Nile was born from permanent sources of water located in two large mountains south of Egypt. More interesting was the investigation of the Greek geographer Claudius Ptolemy in the second century AD, who wrote an extensive book with maps of the different regions collecting all the ideas of the time. These maps were copied until the Modern Age and had an extraordinary influence (Figure 5). Ptolemy collected information about a trip made in the first century by a Greek merchant from the East African coast inland, to reach two large lakes and snowy mountains (which is why he called them "mountains of the Moon"), from where the Nile River emerged. In this respect, both historical texts (The Periplus of the Eritrean Sea, probably written in the first century) and recent archaeological data (Greek and Roman findings along the Red Sea and the Indian Ocean coast) show that Mediterranean and Arab mer-

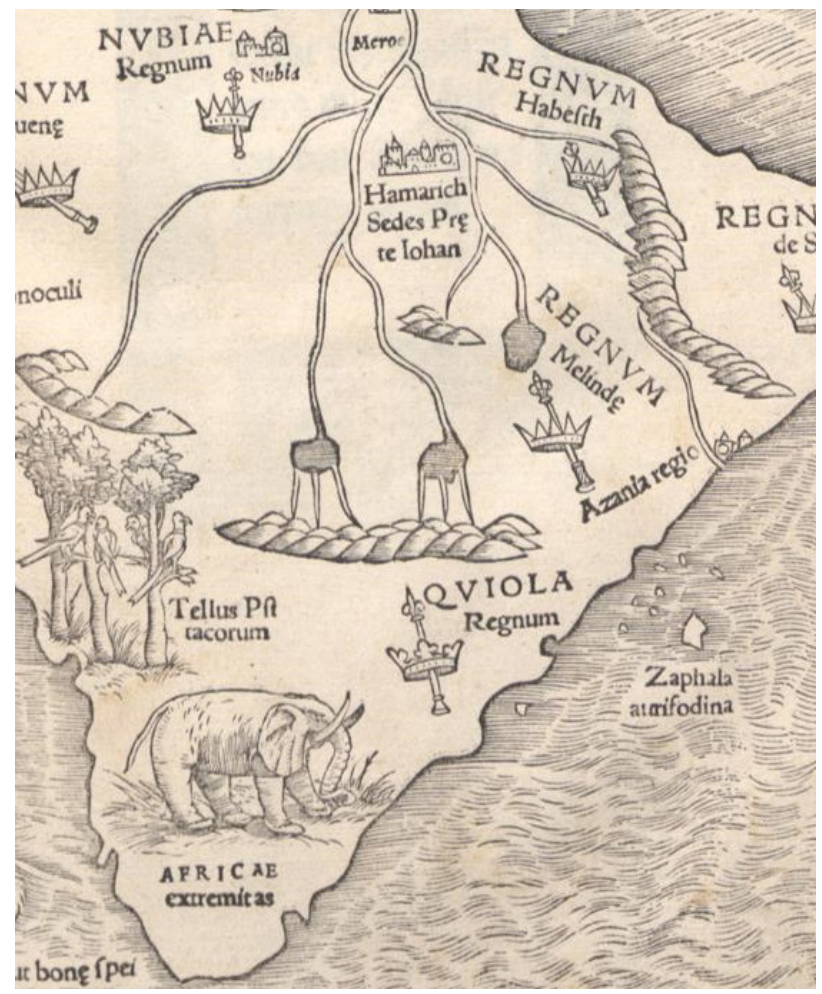

FiguRE 5. A fragment of the Nile region and southern Africa from the Sebastian Münster's map (1554) following the classical ideas of Claudius Ptolemy. The shape of the continent is correct after the Portuguese circumnavigation at the end of the $15^{\text {th }}$ century (Wikipedia Commons).

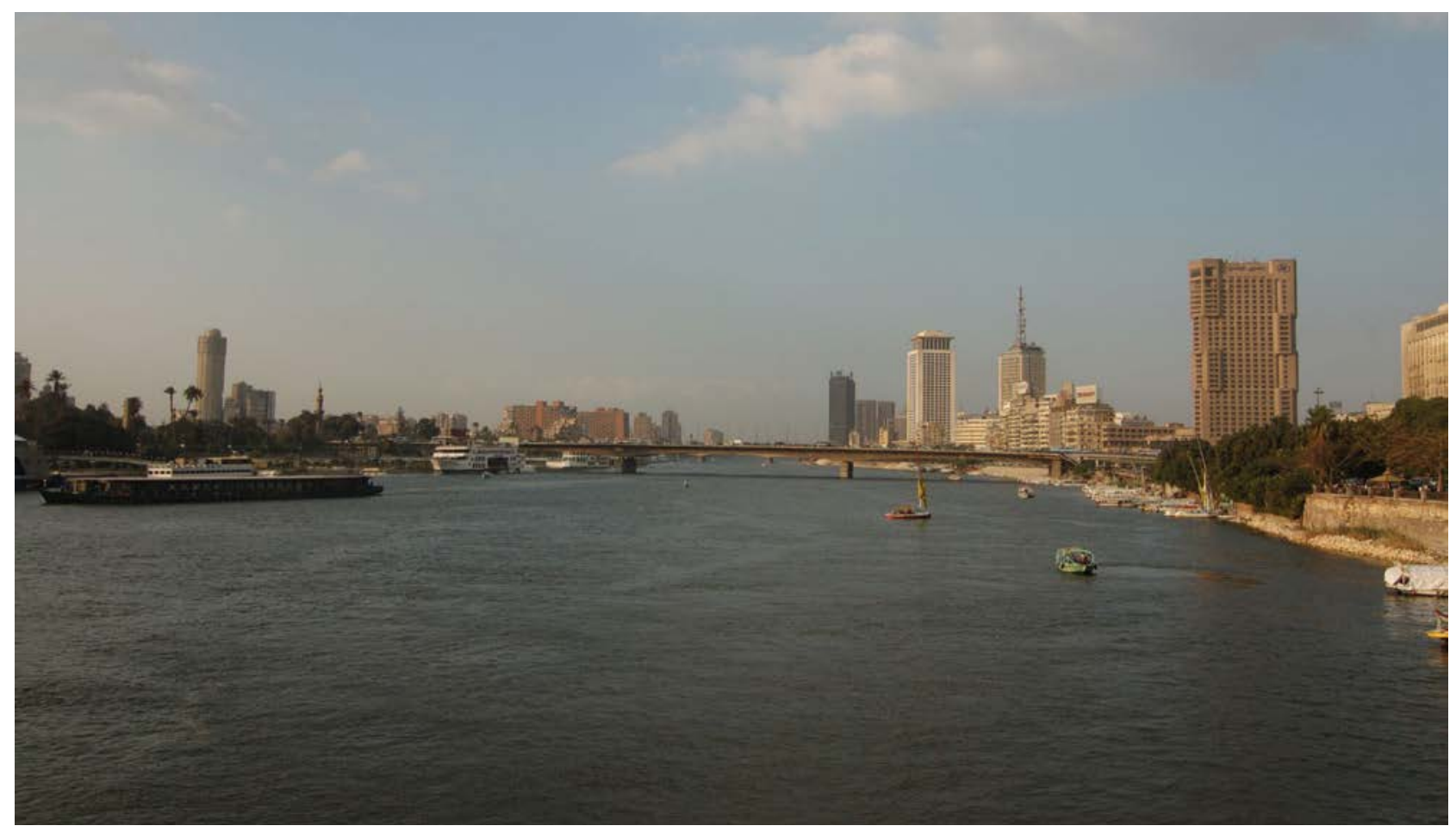

Figure 4. The Nile River in Cairo (Wikipedia Commons). 
chants had come a long way southwards along the eastern African coast (Horton and Middleton, 2000: 32-37). On the other hand, since the White Nile passes through the two great lakes of the region (Victoria and Albert) and there are mountainous massifs with winter snows in the same area (Ruwenzori), the version collected by Ptolemy was not so fanciful for its time.

Throughout the Middle Ages the previous ideas were maintained: The Earthly Paradise, the two lakes and the Mountains of the Moon (along with big animals, dragons and other mythical beings) are represented in most of the maps elaborated at that time. Although the Christian kingdom of Ethiopia (which at the end of the Middle Ages was identified in Europe as being ruled by a legendary and saintly priest-king, the "Prester John") had relations with Coptic Egypt since the fourth century, scarcely any authentic information on the Ethiopian Nile ("Blue" because of its dark colour due to the sediments it carries) arrived to Europe. While it is possible that some medieval travellers saw the Lake Tana and the main course that overflows it, none seems to have arrived at the proper river sources (Crawford, 1949, Arbel, 2000).

Meanwhile the Arab geographers of North Africa also intervened in the matter, especially Al-Idrisi in the $12^{\text {th }}$ century and Ibn Battuta in the $14^{\text {th }}$ century (Levtzion, 2000). They also followed the ideas of Ptolemy, but since the middle of the eighth century they had information about several rivers south of the Sahara, thanks to the caravan trade with the kingdoms of the Sahel. Not surprisingly, the largest river in the region, which crosses the desert for a long stretch before returning to the south into the Atlantic Ocean, the Niger, was identified with the Nile or one of its tributaries, believing that it always flowed eastward, and he same was thought about the Senegal River, which farther west flows into the same ocean. Other rivers that were included in a single eastward-system linked to the Nile were the Chari (which flows into Lake Chad) and the Bahar al-Arab and Bahar al-Ghazal; in the last two cases correctly, since both join the White Nile through the wide swampy area of the Sudd in southern Sudan.

\section{THE CONTRIBUTION OF THE PORTUGUESE AND PEDRO PÁEZ}

The first comprehensive and reliable report on Ethiopia in general published in Europe was written by the aforementioned chaplain Francisco Alvares, who accompanied the Portuguese embassy of Rodrigo de Lima to the Preste in 1520 (Verdadera informaçam das terras do Preste Joam..., Lisbon 1540; today often quoted in the English translation and study by Beckingham and Huntingford, 1961). Alvares did not get to see the river, known in Ethiopia as Abbay, but he stated that some members of the embassy reached its sources, which were in the kingdom of Gojjam and consisted of two great lakes, as big as seas, and that there were some islands at the beginning of the river (Ibid.: 517; 458459). From this it can be deduced that they saw the exit of the river from Lake Tana (although this is a single lake), in which there are several islands, but not the true origin, which would be the birth of the largest tributary of those that discharge their waters to the lake (Yihun et al., 2013) (Figures $6 \& 7$ ). This is the modern idea of

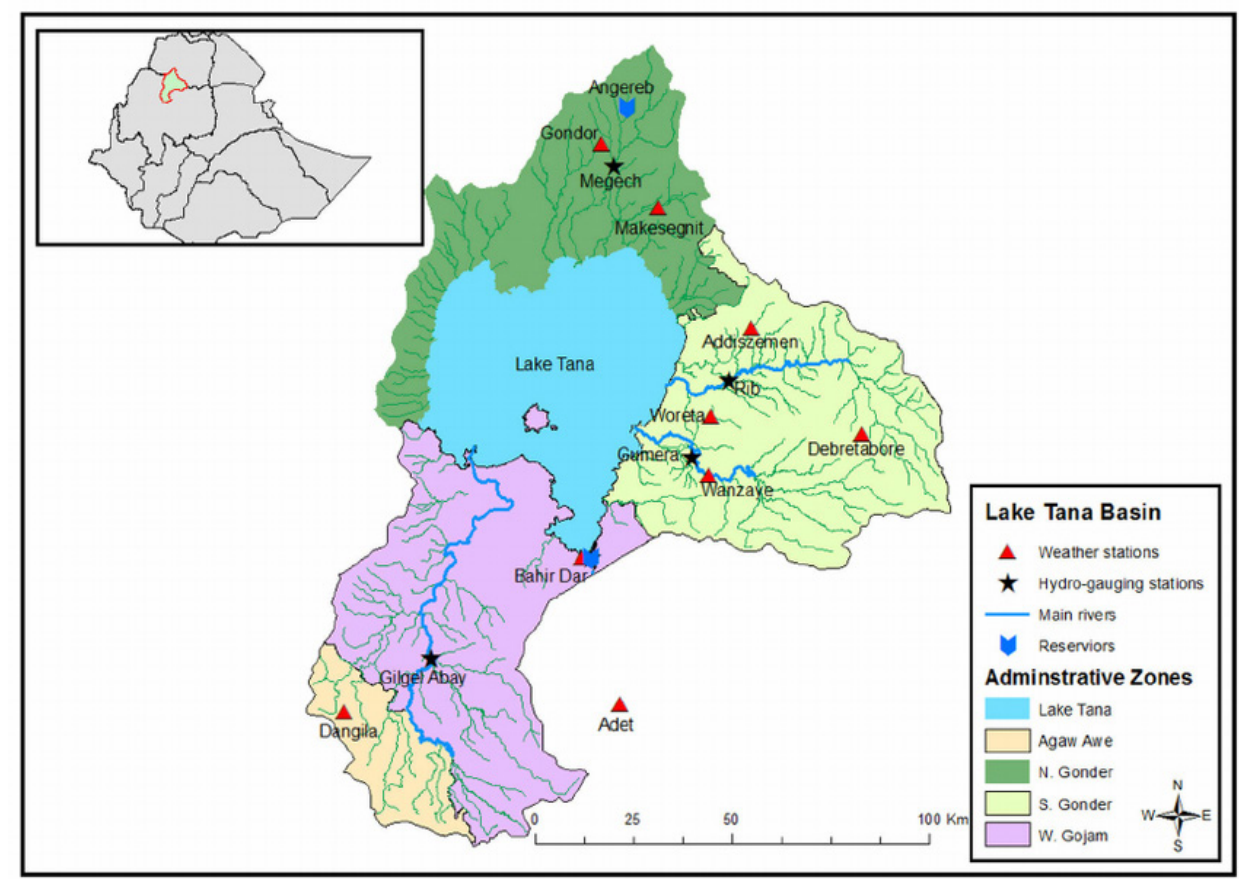

FIgURE 6. Hydrological system of Lake Tana, with the Gilgel Abbay river system to the south of the lake (after Yihun et al. 2013: fig. 1; Open Access publication). 


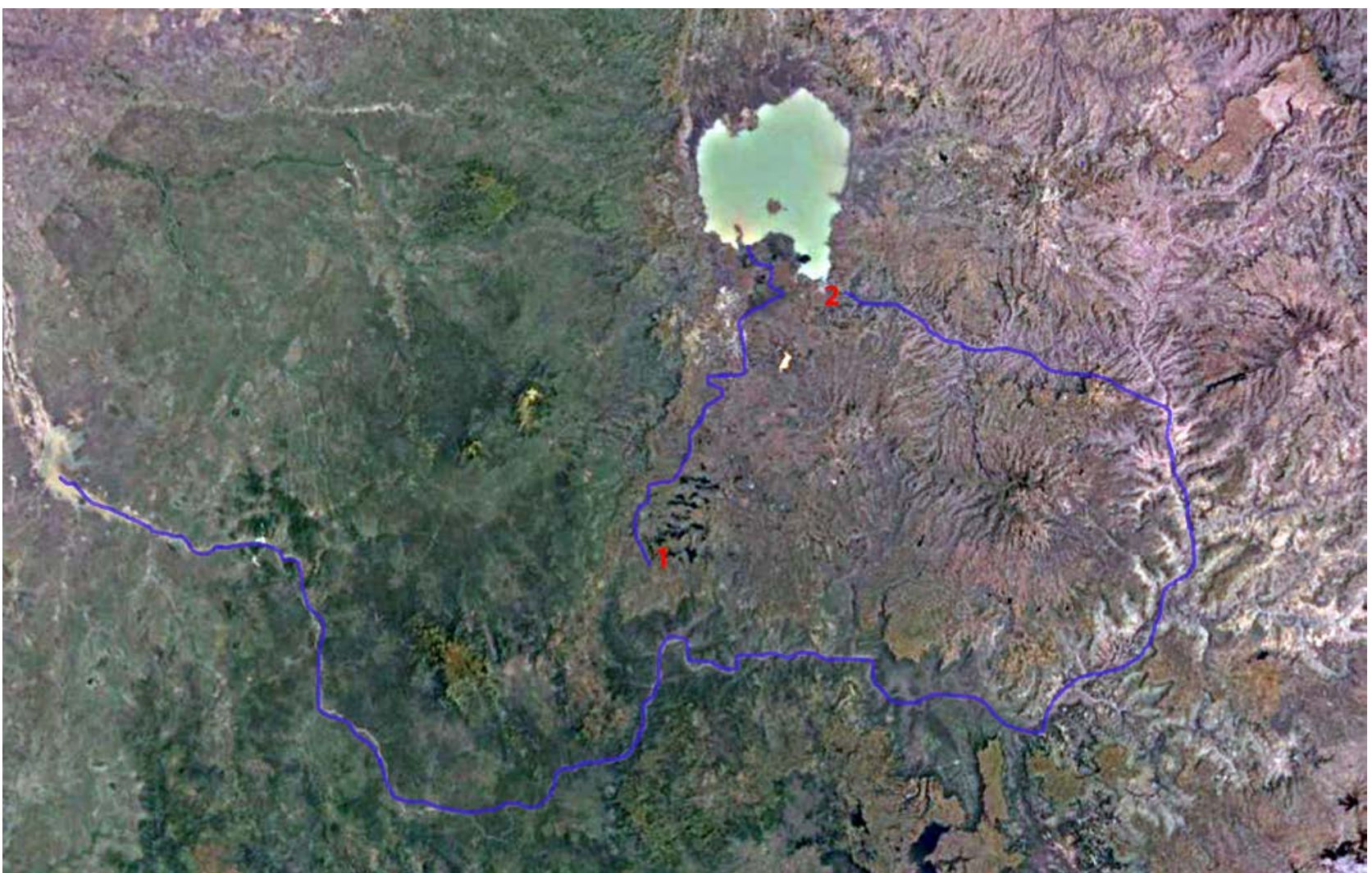

Figure 7. The Lake Tana and Blue Nile basin in Ethiopia. No. 1 indicates the Gilgel Abbay sources and no. 2 the overflowing point of the Big Abbay from the lake. In blue colour, the approximate course of both rivers (Google Earth).

the sources of any river according to the main geographical institutions (such as the American Geological Survey, Smithsonian Institution or National Geographic Society; see "River Source" in Wikipedia, article consulted on April $\left.6^{\text {th }}, 2018\right)$, and it is also the definition applied today to the sources of the White Nile, whose farthest point is on a small tributary of the Kagera River located in Rwanda, south of Lake Victoria (ibid., see below). However, other scholars think that the source should rather be in the large lakes where most of the water comes from, Lake Victoria in the case of the White Nile, and Lake Tana in the Blue Nile (for example, see this viewpoint in two classical dissemination works on the river: Ludwig, 1937: 109, Moorehead, 1986: 32; see also the same opinion by biological researchers in Vijberger et al., 2009: 183), yet this position seems to be rejected today in most geographical circles.

Another novel information provided by Alvares was that the famous annual floods of the river were due to the heavy monsoon rains of the Ethiopian summers. All these data were known in Europe very soon thanks to the inclusion of a translation of Alvares' book in the series Navigazzioni e Viaggi by the Venetian Giovanni Battista Ramusio, published between 1550 and 1559 . One factor that despite this delayed the spread of the new information was that the Portuguese would post- pone publishing many of their reports, which were considered secret as they concerned their commercial plans in the Indian Ocean. Also because of the prestige that the writings of classical antiquity had just recovered, especially those of Ptolemy that paradoxically were relatively erroneous when compared with the fresh and real data then coming from the field. This contributed to maintain many ancient and medieval legends historically associated, such as the Niger River being linked with the Nile or the Nile itself coming from India, along with references to the Mountains of the Moon, the two lakes, the Earthly Paradise, the fluvial beds of pure gold, the existence of dragons and other fantastic beasts near the river, etc. (Arbel, 2000: 115).

Although the intentions of the missionaries' Portuguese and Spanish royal patrons were basically of a pragmatic kind (control of trade with India and gaining a powerful ally in the rear of the Ottoman Empire), the explicit reason of Ignatius of Loyola when he planned the mission to Ethiopia was the spiritual attention to the community of Catholic "Portuguese" who lived there, around 150 soldiers of Christovão da Gama's army who remained at the end of the military campaigns of 15411543, and their descendants (Martínez, 2010b). Thanks to their military knowledge and modern weapons, the Burtukan (Portugal) entered the service of the respective Ethiopian kings, who held them in great esteem 
and granted them land and property. Very soon they established families and relations and by 1560 their number was already estimated at 1200; in the final years of the mission they had reached the number of about 3000 people. After the expulsion, although some left the country with the missionaries and a few clandestinely preserved their religion, most were forced to convert to Orthodoxy or were expulsed (curiously, to the Sinnar sultanate in Sudan, where the Muslim authorities apparently admitted them) and their footprints were lost. This half-breed group was very active during the mission, collaborating with the Jesuits in all kinds of activities, religious, economic or military. Their knowledge of the territory, customs and languages was essential in the work of evangelization.

On the knowledge of the Nile river by that group, Father Luis de Azevedo wrote in a letter sent from Fremona to the Provincial of Goa, on June 22, 1607, that a group of soldiers, "filhos de Portuguezes" (sons of the Portuguese), had visited the sources of the Blue Nile near the current village of Gish Abbay. They consisted of several small streams that came out of the ground at the foot of a small mountain, between the kingdoms of Gojjam and Damot, a place that the pagan natives (of the Agaw ethnic group) considered holy, sacrificing oxen and cows there (RASO, XI: 128) (Figure 8). The leader of that group was João Gabriel, an important personage who is mentioned in numerous occasions by the Jesuit texts (Capitão dos
Portuguezes, Dux Lusitanorum), including those by Páez, always in very laudatory terms. The famous Italian Ethiopianist Carlo Conti Rosini published an article in 1941 where he tracked down the personality of Gabriel, discovering in the texts that he was probably the son of a Venetian soldier who had accompanied Gama, Francesco Gacomo, head of the Luso-Ethiopians between 1559 and 1577, and of an Ethiopian Catholic woman with a reputation for sanctity (Conti Rossini 1941). It seems that Gabriel wrote his own memories in Portuguese, where perhaps he mentioned his visit to the sources of the river, yet this text unfortunately has been lost (Boavida, 2005).

The local tradition still believes today that the waters of the small river travel unmixed with those of the rest of the lake until they leave it by the overflowing big river next to the city of Bahir Dar (Henze, 2000: 39) (Figures $9 \& 10$ ). Another example of continuity we have in the attribution of religious-magical potential to the sources, described by Gabriel and then by Páez, which was collected again in the book that the Scottish explorer James Bruce wrote in 1790 (Bairu, 2000: 158-159), and still holds today, when the site is occupied by a small church where people goes to collect the holy water (see fig. 8). Downstream after the lake, the Blue Nile flows through the famous Tisisat Falls and then enters the deep gorge that marks its full course until shortly before reaching the Sudanese border (Figures $11 \& 12$ ).

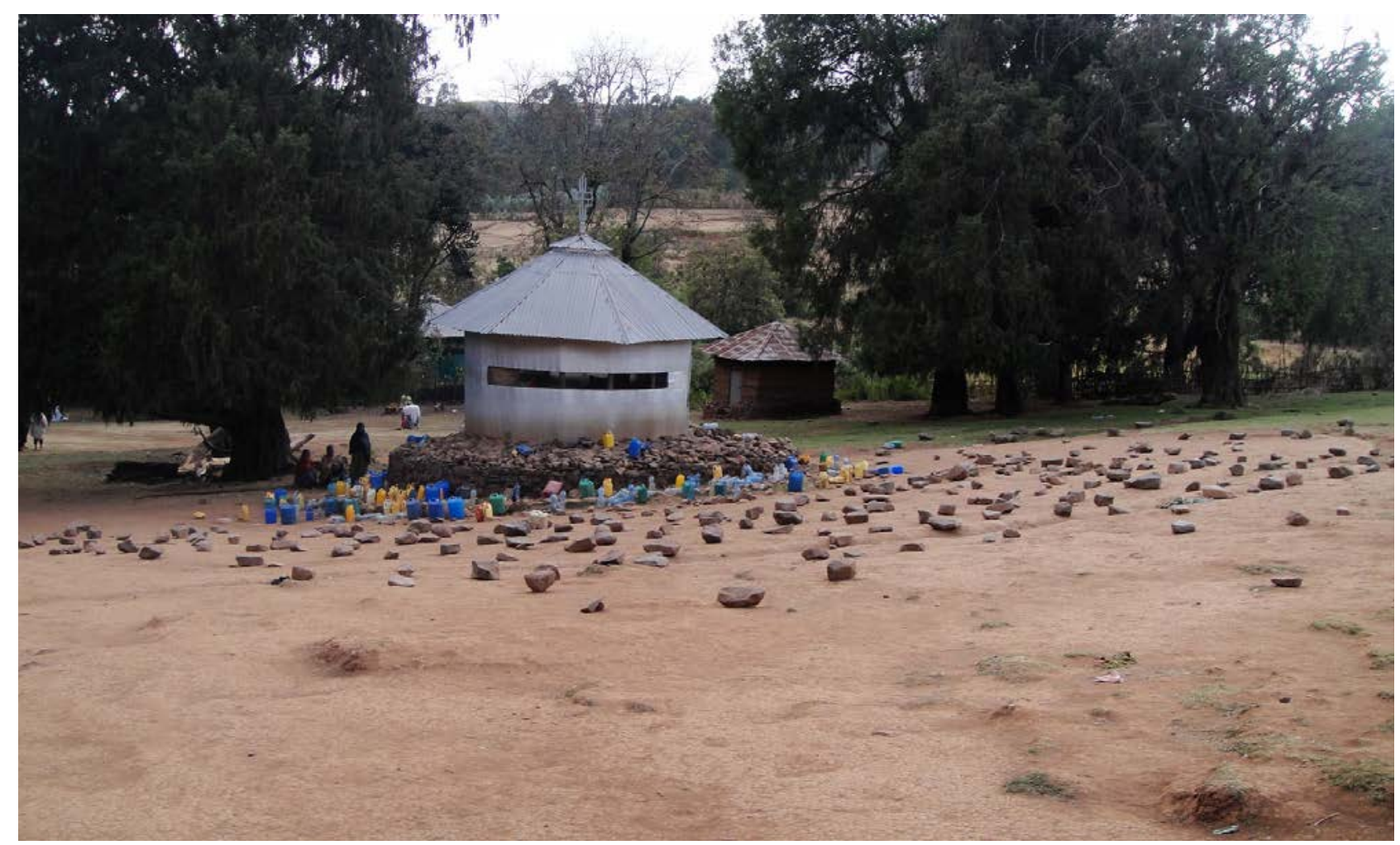

FIGURE 8. The small church over one of the Gilgel Abbay sources, with plastic bottles around to collect the holy water. Author's photograph, Feb. 2012. 


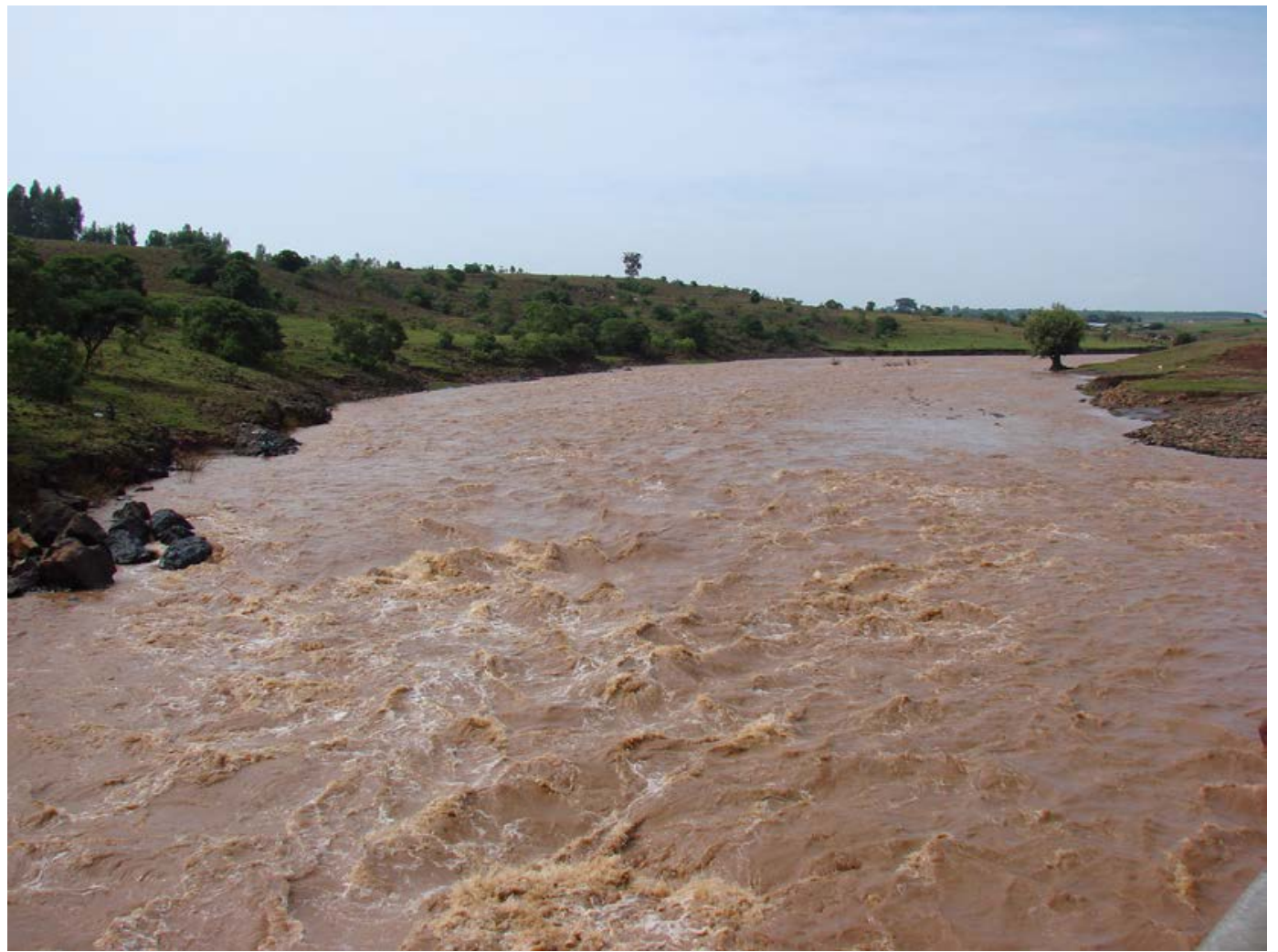

Figure 9. The Gilgel Abbay from the bridge of the Addis Ababa-Bahir Dar road. Author's photograph.

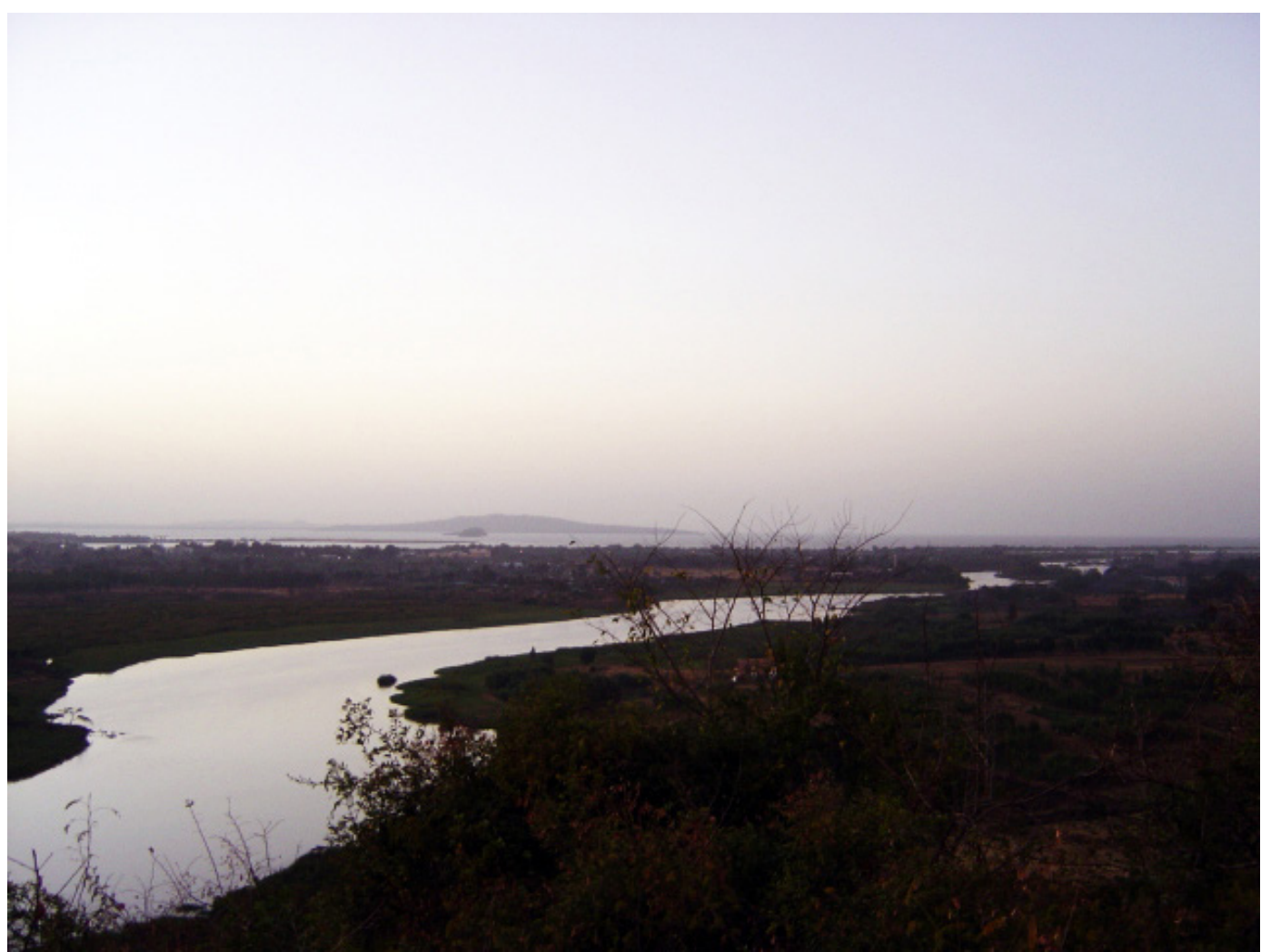

FIgure 10. The Blue Nile at the exit from the lake Tana, seen in the background. Photo by Carmen Ortiz. 


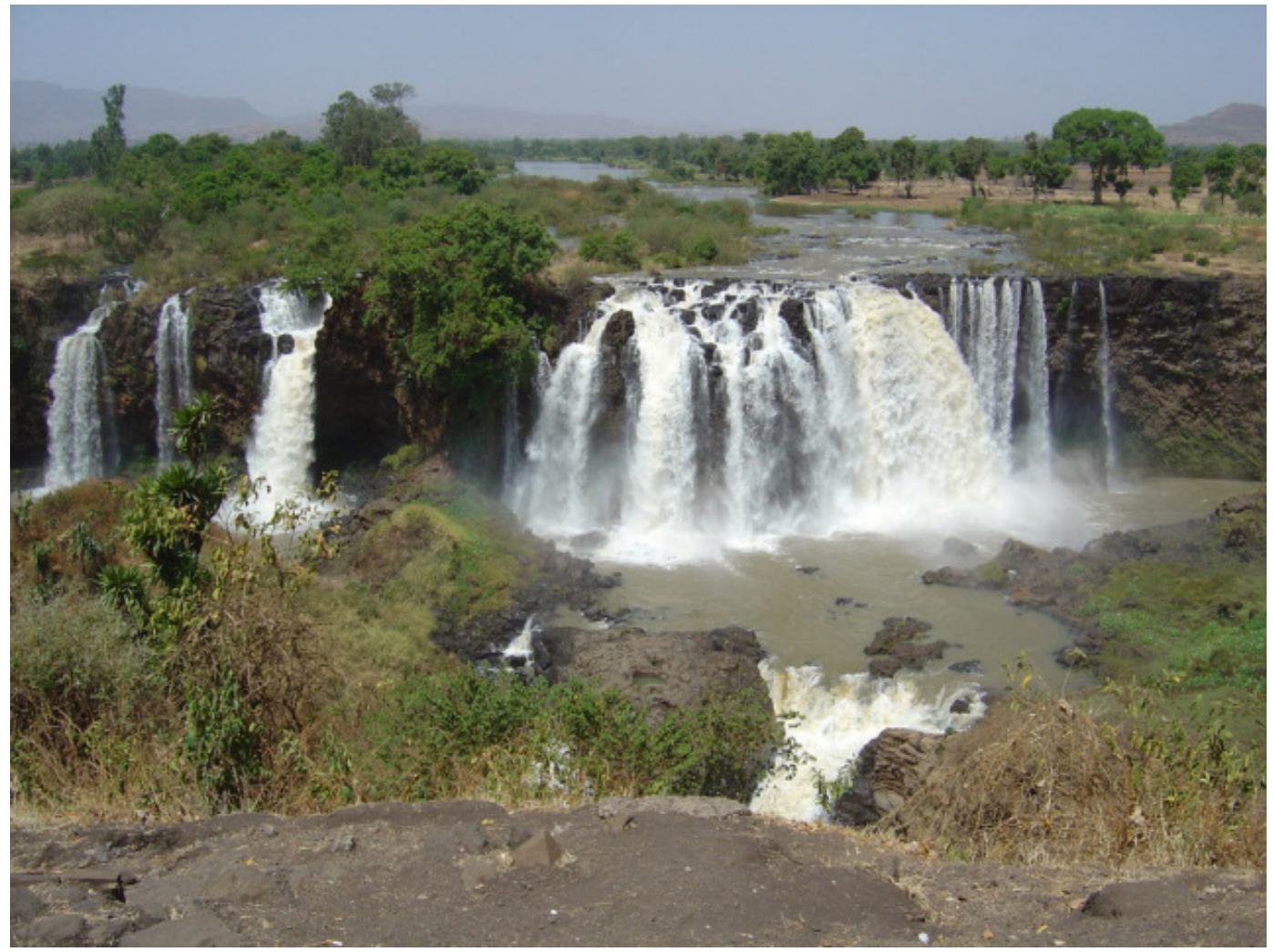

Figure 11. The Tisisat waterfalls. Author's photograph.

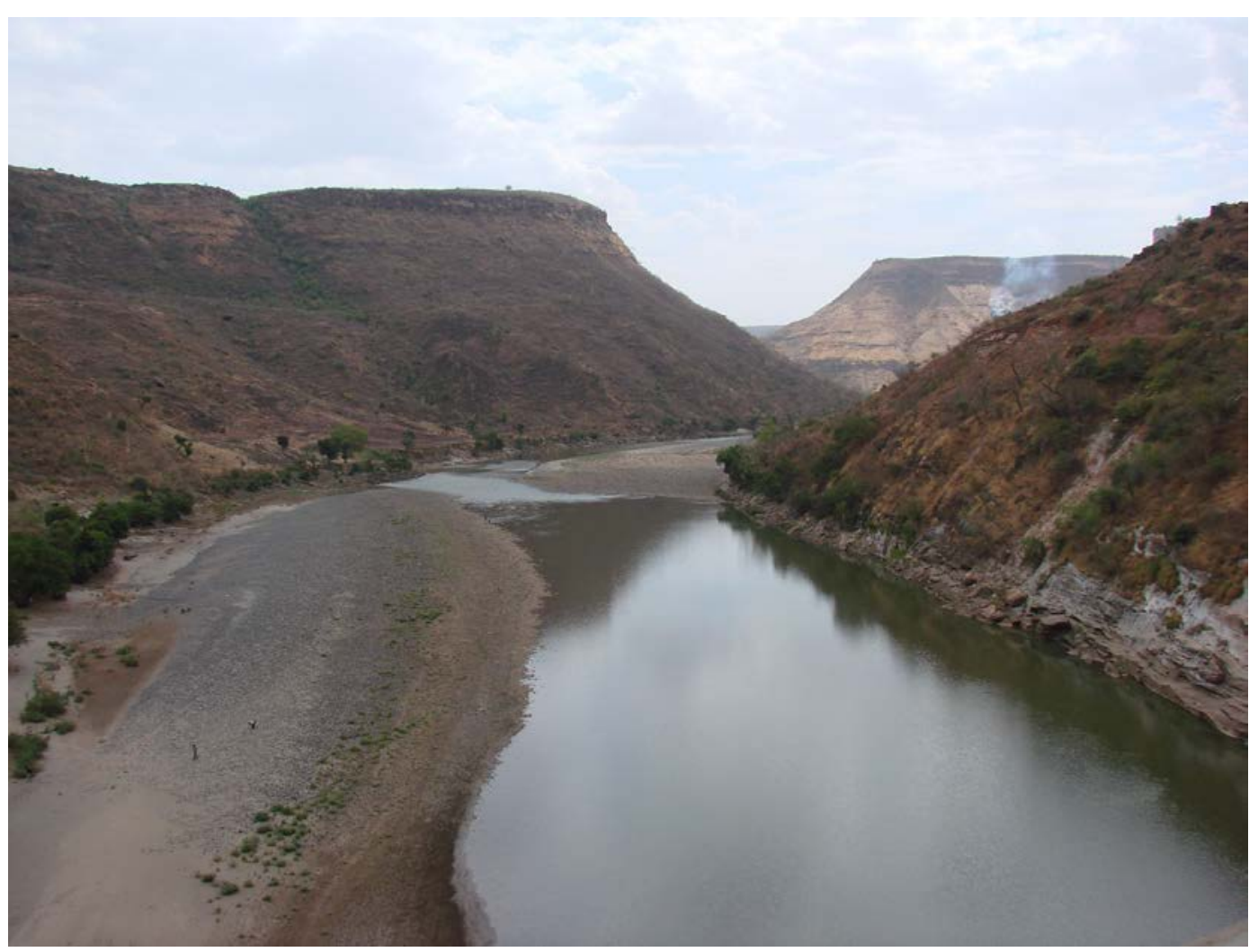

FIgure 12. The Blue Nile Gorge at the Shafartak bridge in the Addis Ababa-Bahir Dar road. Author's photograph. 
It is interesting that Gabriel declared that those were the true sources of the river, according to Azevedo in his report. It seems unlikely that the Portuguese soldiers had by then explored the whole Tana basin and discovered that the "little Abbay" (Gilgel Abbay) was the longest river in the basin and therefore that its birth was also that of the "great Abbay" or Blue Nile. Of this fact they had to be informed by the local people, which suggests that the natives already knew those sources as such since long before the arrival of the Europeans. It is also significant that Páez went to visit the site accompanying the retinue of the king and that Gabriel probably did it in the same way before, suggesting that the source of the river was also known to the royalty, probably not only as a magical or holy place, but as an important geographical site. This largely demystifies the supposed "discovery" or resolution of a geographical enigma by a European, specifically Páez, although he was the first to disclose the location in writing to a European audience.

As Páez wrote in chapter 26 of book I of his Historia de Ethiopia, dedicated to the Nile ("Of the Nile River, its source and its course, and causes of its floods"): "There is the source, almost to the west of that kingdom [Gojjam], at the head of a little valley that becomes a large field. And, on April 21, 1618, when I got to see it, they looked only like two round eyes of four spans wide, and I confess that I was glad to see what King Cyrus and his son Cambyses, the great Alexander and the famous Julius Caesar, wanted so much to see in the past"(RASO, III: 255; Páez 2009: 341). The interest of the ancient kings for the river origin had come through the classical tradition reintroduced by the Renaissance culture and was well known to Páez: in his writings on the wars of Caesar, the Roman poet Lucanus referred to his great interest in the sources of the Nile, as well as that expressed previously by Alexander the Great (Asso, 2011: 353).

Next, Páez describes the course of the river to the lake and then the exit of it, with the famous Tisisat waterfalls, in addition to its later course to reach Sudan in Fazcolo (Fazugli) and to continue later through the land of "gentile Kaffirs" until Cairo. It also belies the many legends that were about the annual floods of the river, as the one explaining them by the heat of summer that made the earth explode and free the water inside. Although Alvares had already attributed the floods to the Ethiopian rains, Páez points out that the high plateau summer really corresponds to a winter climate because of the intense monsoon rains coming from the Indian Ocean, and that when Lake Tana fills up in mid-August, the water begins to reach its maximum. In the following paragraphs he describes some river animals, such as the hippos and the electric fish or torpedo fish, of which he tells an anecdote that happened to João Gabriel.

Later, he denies one of the most persistent myths about the Nile, both in North Africa and in Europe: that it was possible to divert its course and deprive the lands of Sudan and especially of Egypt, where the desert is more extensive, of a vital resource for its inhabitants (Pankhurst, 2000). Since antiquity it was known that some years the flood of the Nile was lower than usual, causing droughts and famines (the "lean years" of the Bible, Genesis, 41). Later on, when Egypt was conquered by the Arabs and converted to Islam in the seventh century, and problems began for the unconverted Christian population (Copts), among the latter and the Ethiopian Christians the idea began to take shape that the big droughts in Egypt, as happened in the ninth, eleventh and twelfth centuries according to historical records, could be due to a divine intervention in the headwaters of the river as a punishment to the Egyptian Muslims. Some traditions record that in the eleventh century the Fatimid Sultan of Cairo sent the Egyptian Coptic patriarch to Ethiopia to implore the Abyssinian king to restore the course. Two important modern writers who collected a wealth of historical information about Ethiopia, both from oral and written sources, the German Hiob Ludolf (16241704) and the Scottish James Bruce (1730-1794), testify that the belief was widespread of the prospect of diverting the waters towards the Red Sea, only by moving the lands of a single mountain to achieve it. The same idea appears in several Ethiopian royal chronicles and in the Arab annals of North Africa (Pankhurst, 2000). The legend did not take long to reach Europe, and a phrase is often quoted from the play Orlando Furioso by the Italian poet Ludovico Ariosto (1532), where another recurring fantasy appears, namely that the sultan of Egypt paid an annual tribute to the Ethiopian negus to continue allowing the waters to flow (Páez also collects the idea and cites the inflated figure of an annual tribute of 300,000 gold sequins - 3.5 grams of gold per each, that is, one ton of gold per year).

When Páez told about these legends to the king and his entourage, "everyone laughed a lot about the fable", saying that not only had they never done it, but they did not by far have the capacity to accomplish it, something that anyone who knows minimally the Ethiopian rugged orography could attest today without any doubt. The missionary also denies other stories about the rains sometimes missing for many years, stating that in the nearly twenty years that he had been in the country he had never seen them fail, but rather the opposite, with years of so intense rains that practically prevented the journeys of the Jesuits. Despite these and other refutations, the idea of diverting the waters showed an extraordinary resistance to disappearing and continued to be repeated over and over again, until perhaps its last implausible appearance, in a letter that Samuel White Baker, the discoverer of the sources of the White Nile along with Speke, wrote to the Times as recently as 1888 , claiming that he had seen a place where the river could be diverted to the Red Sea (van Donzel, 2000: 127).

Some recent facts show, however, that the idea of controlling the Nile is not something that belongs entirely to the past. On the one hand, its flow remains irregular and there are still periods of severe drought such as the one that in 1987 caused an unprecedented descent of the waters of Lake Nasser in Egypt, raising fears even that the river will dry up due to the current climate change (Erlich and Gershoni, 2000: 3). More important is that, with the current technology, although it still does not allow the di- 
version of waters in a mountainous country such as Ethiopia, it is possible to build large dams that affect the river course. Apart from the large Aswan dam in Egypt, and the more recent and smaller ones of Sudan, the Ethiopian government is about to end up on the Blue Nile the largest dam in Africa, which was named first the "Millennium" dam (for the year 2000 of the Ethiopian calendar, at the time of its beginning) and now it is called the "Renaissance" dam, a few kilometres before the Sudan border. The concern is being intense in Egypt for the possible reduction of the water volume, especially during its completion when the dam will take several years to fill (up to a total of 1.5 times the full annual flow of the river) and later by the largest evaporation rate at the area. At the time of writing these lines (June, 2018), the conversations between the three countries (which on the subject of water control are already centuries old) continue without reaching an agreement, but at least in theory it seems that an adequate coordination could perhaps result in benefits for all (Wheeler et al., 2016).

Returning to Páez, it is interesting to note that at no time does the missionary present himself as the discoverer or first visitor of the sources (quite the opposite of what James Bruce will do one century and half later). In another paragraph of his chapter, he says that he is accompanying King Susenyos and his army on his visit to the site, that King Särsä Dengel (r. 1563-1597), or his successor Yaeqob (r. 1597-1607), had also camped with his army next to the fountains, and that "today, some of the Portuguese who accompanied him then are with me". It was probably in that visit of the previous king when João Gabriel saw the sources and then transmitted the information to the missionaries, as we saw before.

\section{THE DIFFUSION OF THE DISCOVERY}

Obviously, the attribution to Páez of the first discovery of the river sources by a European comes from the fundamental fact of having collected the observations in writing and that this information arrived relatively soon, for the time, to other interested parties and was incorporated into the treaties and maps of this part of Africa. The manuscript of the Historia arrived quickly in India, and a copy was later returned to Ethiopia to be used in the subsequent writings on the mission and the histories of the region composed by Manoel de Almeida, Baltasar Telles, Afonso Mendes or Jerónimo Lobo. The descriptions of the sources that appear in these works are very similar to that of Páez, so it can be doubted if these missionaries also visited the place. What is surprisingly true is that none of them mentions Páez as the discoverer (Boavida et al., 2009: 65-68). This "forgetfulness" is probably related to other partial censorships of the work of Páez in the later missionary writings and has been explained, also in relation to the absence of Spanish fathers in the final phase of the mission, by the increasing tensions between Spain and Portugal, shortly before the restoration of Portugal's independence in 1640 (Martínez, 2015: 320).
In any case, although the Historia was not published entirely in its time (see supra), the description of the sources soon became part of international scholarship. Thus it appeared in the work of the German Jesuit Athanasius Kircher, Oedipus Aegyptiacus (1652: vol I, 56-59), and was later copied by another member of the order, Kaspar Schott, in Anatomia Phyisco-Hydrostatica Fontium ac Fluminum (1663: 426- 433), where Páez (Petri Pais, Petrus Pays) is expressly mentioned as the discoverer and even part of his original manuscript appears translated into Latin. The multifaceted and prolific Kircher (1602-1680), a master in almost all the Renaissance (and Medieval) sciences, used for his writings a large amount of information that numerous Jesuit missionaries were sending to Rome from the most remote places in the world (Wright, 2005: 75-78), and among them was without a doubt the Historia or at least a part of it (in the Casa Professa of Gesù in Rome, in addition to Milano and Bologna, there were copies at the time of Bruce, see Beccari in RASO, I: 269-270).

Later, the story is well known that James Bruce visited the same sources on November 4, 1770, during his extensive trip to Ethiopia. In his informative memoirs published in 1790, five volumes specifically entitled Travels to discover the source of the Nile, he claimed to have been the first to have arrived there and denied that Páez had done it before (something he had to know necessarily having read it in Kircher; see Bredin, 2000: 164). This was immediately disclaimed by many, among them, when he heard his stories directly by Bruce himself, none other than Samuel Johnson, then a great specialist in Ethiopia after having translated Jerónimo Lobo's Itinerario and written his famous moral fable Raselas (inspired by the Catholic half-brother of king Susenyos, the Ras -governor- Seela Krestos) (Boavida et al., 2009: 65-66).

As far as cartography is concerned, the two most important maps prior to the Jesuit explorations were those known as Egyptus Novelo and the map of Fra Mauro, both very advanced for their time and drawn in what was the best geographical and exploratory centre of the time, Venice, in the mid-fifteenth century (Crawford, 1949). Despite their inaccuracies, many names of rivers and places that appear in them were already correct, and even a few rivers were well represented, such as the Awash that runs through the Rift Valley in Ethiopia towards its endorheic end to the north, but in both maps the Blue Nile source is located far to the south of Lake Tana, from which it then left towards the north, besides containing other inaccuracies and fantasies concerning other rivers such as the White Nile, the Takazé, etc.

In the manuscript of his Historia de Ethiopia a Alta, Manoel de Almeida introduced a map of the NE of Africa summarizing all the data collected by the Jesuits. Apart from some errors for the White Nile, which is not represented, and the Takazé, that appears parallel to the Nile northwards when in fact it connects with it 
in Sudan (with the name of Atbara), the map correctly shows the course of the Blue Nile, with its exit of the lake Tana first towards the southeast and with all its tributaries until Sudan (Figure 13). The little Abbay is drawn to the west of the lake (it actually flows from the south), coming from a small lake that pretends to represent the source, this correctly located in the land of the Agaws (the whole is marked in the map with no. 51, "Fonte do Nilo").

Copies were made and circulated through Europe of this map, which in the copy of RASO VI has a date of 1662 (though at the bottom there is a text indicating its manufacture in 1640 , i.e. already in India and six years before Almeida's death death in Goa). Crawford mentioned two London copies available in the mid-twentieth century, in the British Museum and the SOAS (Crawford, 1949: 19). Although the lack of astronomical instruments on the part of the missionaries (which were already used by sailors, including the Portuguese who drove them to their destinations) prevented them from positioning the part they knew (Ethiopia) with respect to Sudan and Egypt (a huge space that they imagined much smaller) and therefore they were not able to locate the connection to the White Nile and the Takazé to the north (Crawford,
1949: 19-20), this did not preclude more professional geographers from doing so when they soon received the lacking data.

The first of them was one of the last representatives of the great Venetian cartographic tradition, the Franciscan Vincenzo Coronelli (1650-1718), who included a map of Abyssinia in his Atlante Veneto (1690) where Lake Tana and the Blue Nile appear with their correct geographic shape, though the little Abbay is still placed to the west and the lake islands are oversized (Figure 14) (Arbel, 2000: 115). From then on, while the true dimension of Africa was known since its circumnavigation by the Portuguese at the end of the 15th century, the problem was the enormous information gap that existed from the Blue Nile to the southern tip of the Cape of Good Hope. During the eighteenth and nineteenth centuries the hiatus was gradually filled with information from the increasingly well-known coast, and data coming from the inland expeditions by the Portuguese (Congo, Angola, Mozambique) and the Dutch (South Africa). Even so, and although animals and monsters were no longer painted in the empty spaces (or the famous phrase of the medieval maps: "hic sunt leones", here there are lions), either a large blank space was some-

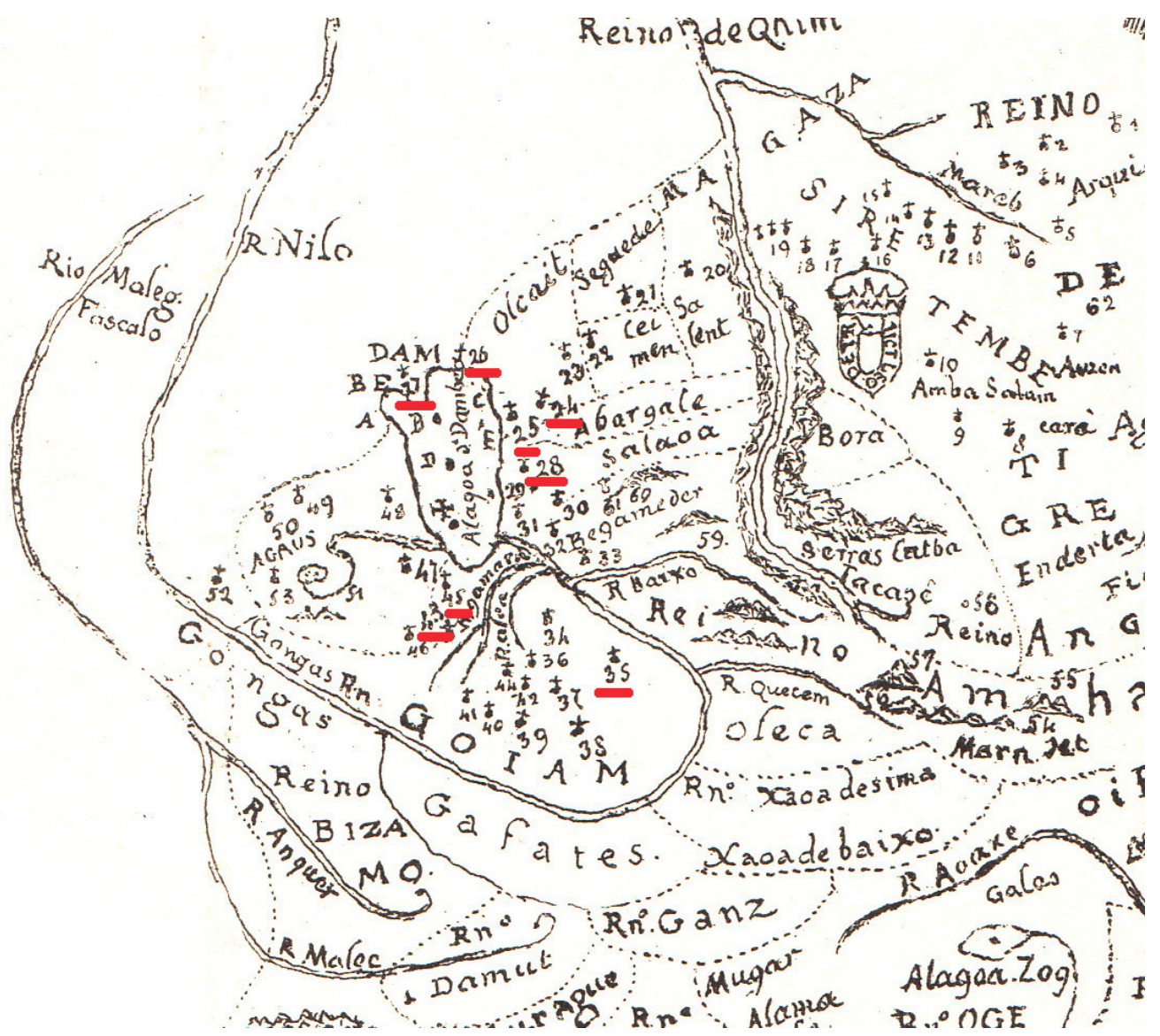

Figure 13. Part of Almeida's map of north-eastern Africa (1662), with the course of the Blue Nile leaving Lake Tana and then turning to the north. The Gilgel Abbay appears wrongly located west of the lake. Underlined in red, the numbers corresponding to the Jesuit missions (RASO VI). 


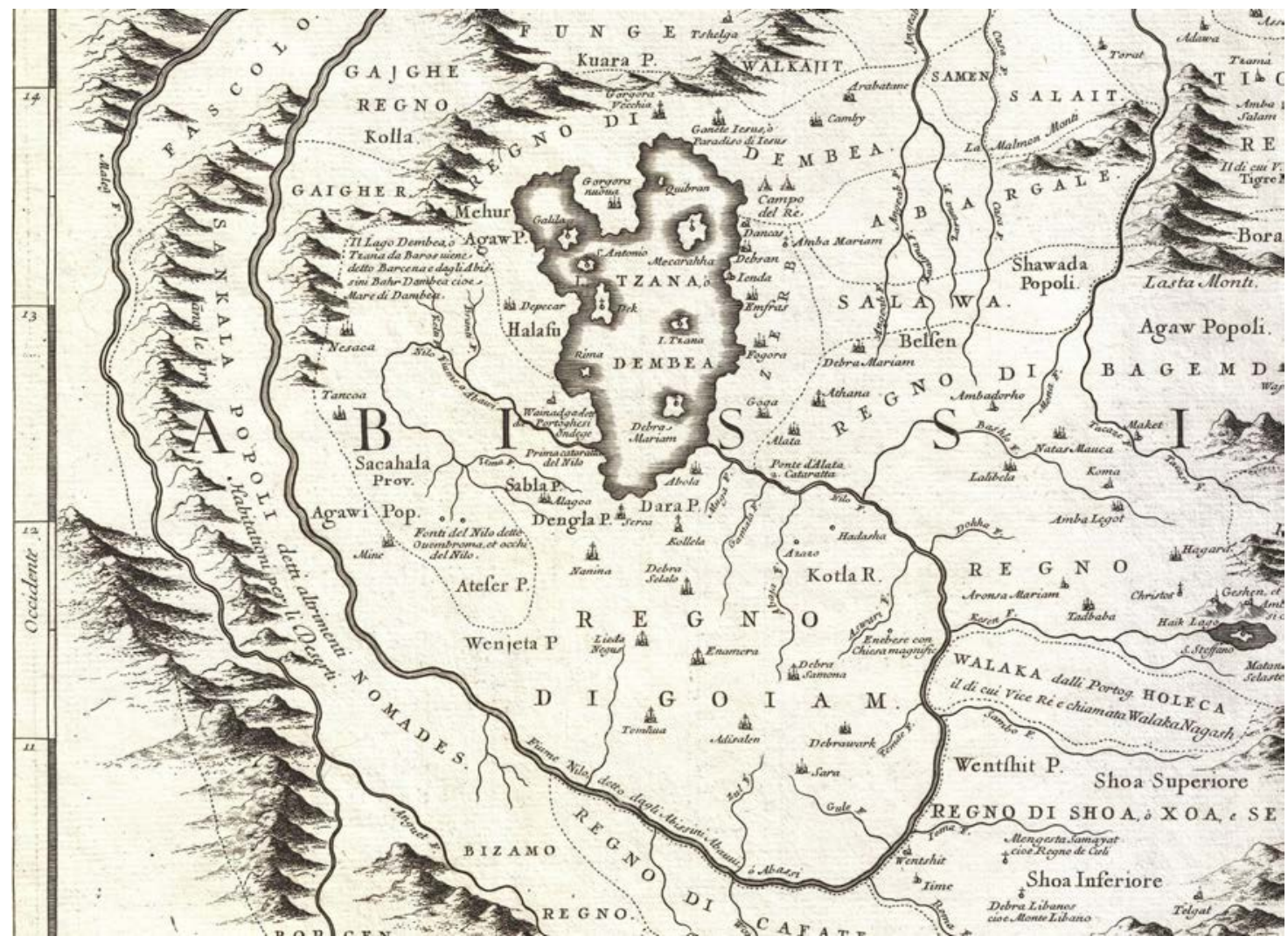

Figure 14. Part of the map of Vincenzo Coronelli (Atlante Veneto, 1690) where the Jesuit discoveries are already incorporated. Wikipedia Commons.

times left, or nonexistent rivers were invented, as the false tributaries that decorated the eastern bank of the upper course of the White Nile, whose origin was still placed in the classic Mountains of the Moon (SáenzLópez and Pimentel, 2017).

Curiously, the two great lakes where the other Nile came from, according to the ancient version of Ptolemy, were the last to be discovered: Lake Victoria and Lake Albert. The reason for the delay was the difficulty of penetrating this area of Africa, one of the unhealthiest in the world besides being affected for centuries by the infamous slave trade, which forced some of the great explorers of the $19^{\text {th }}$ century (Burton, Livingstone, Stanley, Speke, Baker, etc.) to spend their whole life to explore it, when not to lose it in the attempt. John Hanning Speke discovered the exit of the White Nile from Lake Victoria in 1862 but the story did not end there. In 2006, almost 400 years after Páez, a team led by Scottish Neil McGrigor claimed to have discovered the true sources of the White Nile, in the normalized geographical sense that we saw earlier, at a small spring in the mountains of Rwanda, $107 \mathrm{~km}$ above Lake Victoria. There starts the main contributor to that enormous lake, the Kagera River, the finding converting the true total length of the Nile river into 6718 km (Daily Telegraph, April 1, 2006; El Mundo, April 4, 2006) (Figure 15).

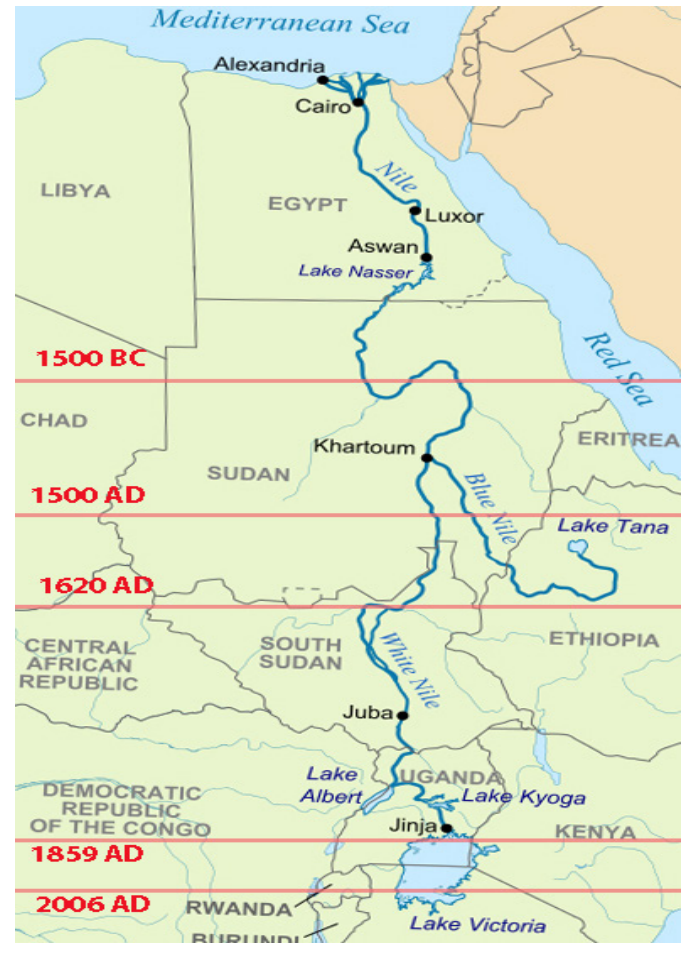

FigURE 15. A very protracted discovery: schematic representation of the dates in which the several parts of the Nile River were revealed. 


\section{THE "PORTUGUESE" BRIDGES ON THE BLUE NILE}

Along the Ethiopian Blue Nile several seemingly ancient, stone-and-mortar bridges are conserved. In his informative 1988 article, the French archaeologist Francis Anfray collected data about a total of 11 bridges, most of them in the Gondär region (Bambulo, Defeche, Korata, Gobatit, Fanter, Tekara, Wemberghe, Tis Abbay, Sabara-Dildiy, Wonghe, Tchaga). The greater part seem to have been constructed during the Gondärine period because of its type of masonry but historical texts or oral tradition state that at least two of them were made by the Portuguese (Tis Abbay, Wonghe). The problem for all of them is that it is very difficult to establish their exact chronology, not only because the type of construction varied little over time but because many were restored several times, or even completely reconstructed, and what we currently see can be quite later than the original.

The only bridge mentioned by the Jesuits is that of Tis Abbay, located downstream next to the famous Tisisat Falls near the city of Bahir Dar (Figure 16). Built between two close rocks on both banks, it has a curved shape with eight arches and is 64 meters long. It is still widely used by the local population and together with the waterfalls it constitutes the main tourist attraction of the area.

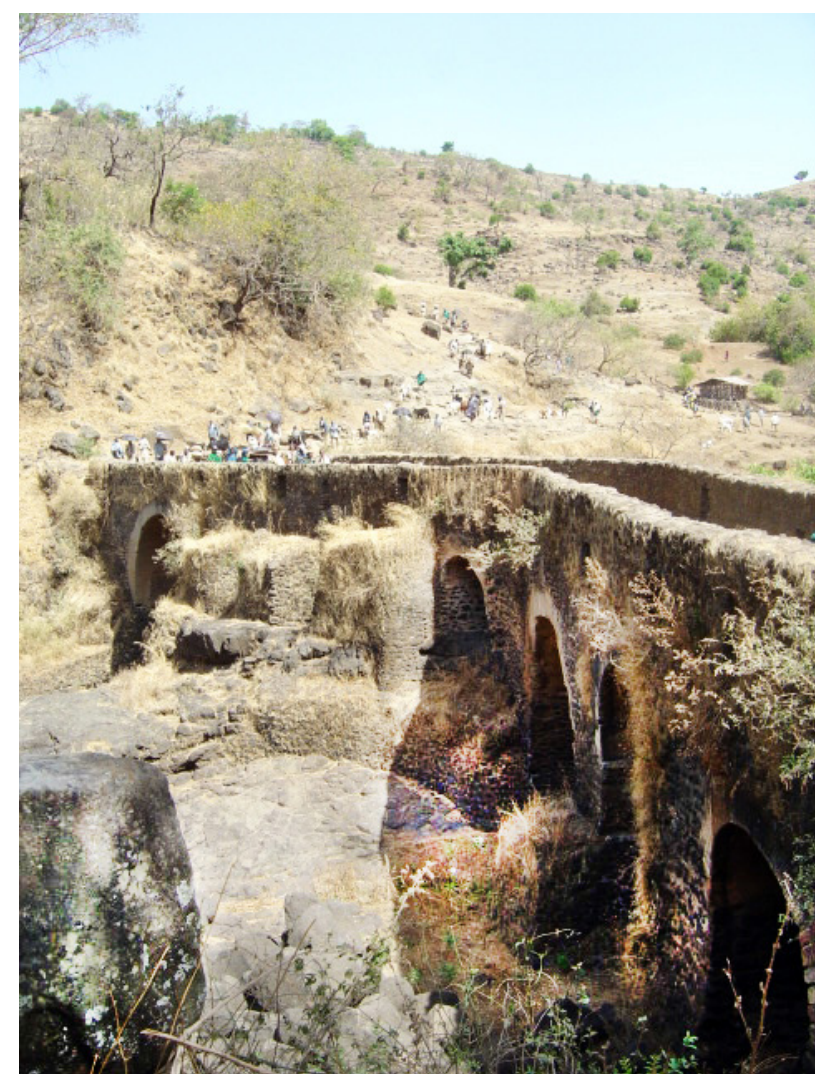

Figure 16. The Tis Abbay bridge over the Blue Nile. Photo by Carmen Ortiz, Feb. 2006.
According to Almeida's description (in RASO, VII: 230231), it was built by an Indian technician (a "gentile") who had come with Patriarch Mendes from Diu, and it was then the first and only bridge of stone and lime seen in Ethiopia. Before the expulsion, the last missionaries passed through this bridge, fleeing the Orthodox persecution from Gojjam to take refuge in Däbsan (Martínez, 2015: 302).

Almeida says that the river under the bridge is very deep and narrow, with large rocks on both sides and before building it people placed two or three large logs over the gap and could cross it. The description coincides with the current place but this is not the case for the bridge itself, because Almeida affirms that it only had one arch, and that three new small arches were added later to overcome the floods of August that covered it partially (RASO, VII: 231). The same description of a single arch ("unicum arcum") appears in the texts by Afonso Mendes (RASO, VIII: 32). From these clear differences, Anfray rightly inferred that the current bridge is not the same as that built by the Jesuits, an idea that he reinforces with recent data about having been repaired at least twice, between 1874 and 1908 and in the 1970s (Anfray, 1988: 1920).

\section{CONCLUSIONS}

It is a well-known fact that the Blue Nile adventure was not by far the only geographical discovery in which Catholic missionaries participated at the beginning of the great European expansion of the Modern Age. Although the mendicant orders (Franciscans and Dominicans in particular) played an important role, the Jesuits were the most prominent in that regard, and we only need to mention in passing some of their essential contributions in the Amazon, Canada and the interior of North America, Central Asia, India, China, Japan, etc. Although their ultimate goal was the conversion of the whole humanity to the faith of Christ, they soon understood that knowledge of countries and customs was essential to achieve it. In this way, and without being fully aware of it, they fulfilled the dual function of significantly promoting the advancement of science and of contributing (also significantly) to the economic plundering that European colonialism entailed. This contradiction is only apparent: historians of science have long ago made it clear that the origin of modern science did not come simply from the pure desire for knowledge, as is often naively believed, but from the need to control new environments in order to dominate them (hence the famous definition that Auguste Comte would later give of science: "savoir pour prévoir, prévoir pour pouvoir").

In the case of the Jesuits, this scientific interest went really very far, partly because of their position, so criticized by their enemies and even at some point by the papacy, of "temporization" or "accommodation": becoming what they wanted to convert or, to use their terminology, "reduce" (Wright, 2005: 128-136). The cases are well-known of Matteo Ricci teaching astronomy and 
dressing like the Chinese sages to impress them, the Jesuits dressed as Brahmins in India, etc. In this regard, it has been said that the Society of Jesus was the only intellectual elite that was then capable of understanding cultures other than Western-Christian "from within", that is, following their own logic (Martin, 1988; Imbruglia, 2006: 166). This condition of the Jesuits as "universal men" was also that of Páez. As Almeida wrote describing his life and death, he was "a slave of all" and faithfully followed the maxim of St. Paul (Corinthians I, 19), which was the basis of Jesuit accommodation: "Omnibus omnia factus sum ut omnes lucrifacerem", I have done everything with everyone, to save them all (RASO, VI: 361).

But resolving the old polemic of science and colonialism is far from the aims and capabilities of this article, which can very well be concluded with an idea by the distinguished British archaeologist, in this case turned geographer with the fortune that characterized all his work, Osbert G.S. Crawford (1949: 6). In contrast to what happened in the fields of geology and astronomy, where the Christian church was a delaying element (remember the infamous case of Galileo), in geography and cartography it was the missionaries (then only Catholics) who made substantial progress in the knowledge of the planet at the beginning of the Modern Age. The professional geographers had it more difficult because of the fear of confronting the great classical tradition then recently recovered, in its field represented by the lasting errors of the great Ptolemy.

Madrid, June 2018

\section{REFERENCES}

Arbel, Benjamin (2000) "Renaissance Geographical Literature and the Nile". In The Nile. Histories, Cultures, Myths, edited by Erlich, Haggai and Gershoni, Israel. Lynne-Rienner. Boulder: 105-119.

Asso, Paul (ed.) (2011) Brill's companion to Lucan. Brill, Leiden.

Bairu Tafla (2000) "The father of rivers. The Nile in Ethiopian literature". In The Nile. Histories, Cultures, Myths edited by Erlich, Haggai and Gershoni, Israel. Lynne-Rienner. Boulder: 153-170.

Beckingham, C.F.; Huntingford, G.W.B. (eds.) (1961) The Prester John of Indies. A true relation of the lands of the Prester John being the narrative of the Portuguese embassy to Ethiopia in 1520 written by Father Francisco Alvares. 2 vols., Cambridge Hakluyt Society-Cambridge University Press: 1961.

Bishop, George (2002) Viajes y andanzas de Pedro Páez. Primer europeo en las fuentes del Nilo (1613). Ediciones Mensajero Bilbao.

Boavida, Isabel (2005) “Gabriel, João". In Encyclopaedia Aethiopi$c a$, vol. 2. Edited by Uhlig, Siegbert, Harrassowitz. Wiesbaden: 632-633.

Boavida, Isabel, Pennéc, Hervé and Ramos, Manuel João (eds.) (2009) "Introducción". In Historia de Etiopía by Pedro Páez, edited by Boavida, Isabel, Pennec, Hervé, Ramos, Manuel João. Fundación El Legado Andalusí. Granada: 23-83.

Bredin, Miles (2000) The Pale Abyssinian. The Life of James Bruce, African Explorer and Adventurer. Flamingo, London.

Caraman, Philip (1985) The Lost Empire. The Story of the Jesuits in Ethiopia 1555-1634. Sidgwick \& Jackson. London.

Cohen, Leonardo (2009) The missionary strategies of the Jesuits in Ethiopia (1555-1632). Harrassowitz. Wiesbaden.
Conti Rossini, Carlo (1941) "Le sorgenti del Nilo Azzurro e Giovanni Gabriel". Bolletino de la Reale Società Geografica Italiana, VII (VI): 38-47.

Crawford, O.G.S. (1949) "Some medieval theories about the Nile". Geographical Journal, 114: 6-23.

Crummey, Donald (2000) Land and society in the Christian kingdom of Ethiopia, from the thirteenth to the twentieth century. University of Illinois-Addis Ababa University. Urbana-Addis Ababa.

Erlich, Haggai; Gershoni, Israel (2000) "Introduction”. In The Nile. Histories, Cultures, Myths, edited by Erlich, Haggai and Gershoni. Israel, Lynne-Rienner. Boulder: 1-14.

Fernández, Víctor M. (2013) "Enlivening the dying ruins: History and archaeology of the Jesuit missions in Ethiopia, 1557-1632". Culture and History Digital Journal, 2(2).

Fernández, Víctor M.; Torres, Jorge de; Martínez d'Alòs-Moner, Andreu and Cañete, Carlos (2017) The Archaeology of the Jesuit Missions in Ethiopia (1557-1632). Brill. Leiden.

González Núñez, Juan (1990) Etiopía: hombres, lugares y mitos. Mundo Negro. Madrid.

Henze, Paul (2000) "Consolidation of Christianity around the source of the Blue Nile". In The Nile. Histories, Cultures, Myths, edited by Erlich, Haggai and Gershoni. Israel, LynneRienner Boulder: 39-56.

Horton, Mark; Middleton, John (2000) The Swahili. The Social Landscape of a Mercantile Society. Blackwell. Oxford.

Imbruglia, Girolamo (2006) "Un imperio d'età moderna: la compagnia di Gesù". In Le problème de l'altérité dans la culture européenne. Anthropologie, politique et religion aux XVIII et XIX siécles, edited by Abbattista, Guido and Minuti, Rolando. Bibliopolis. Nápoles: 159-178.

Levtzion, Nehemia (2000) "Arab geographers, the Nile, and the history of Bilad-as-Sudan". In The Nile. Histories, Cultures, Myths, edited by Erlich, Haggai and Gershon, Israel. Lynne-Rienner. Boulder: 71-76.

Ludwig, Emil (1937) The Nile. The Life-Story of a River. The Viking Press. New York.

Martin, A. Lynn (1988) The Jesuit Mind. The Mentality of an Elite in Early Modern France. Cornell University Press. Ithaca.

Martínez d'Alòs-Moner, Andreu (2010a) "Páez, Pedro". In Encyclopaedia Aethiopica, vol. 4 Edited by Uhlig, Siegbert, Harrassowitz. Wiesbaden: 89-90.

Martínez d'Alòs-Moner, Andreu (2010b) "Luso-Ethiopians". In Encyclopaedia Aethiopica, vol. 4 Edited by Uhlig, Siegbert, Harrassowitz. Wiesbaden: 182.

Martínez d'Alòs-Moner, Andreu (2015) Envoys of a Human God. The Jesuit Mission to Christian Ethiopia. Brill. Leiden.

Merid Wolde Aregay (1984) "Society and technology in Ethiopia, 1500-1800". Journal of Ethiopian Studies, 17: 127-147.

Merid Wolde Aregay (1998) "The legacy of Jesuit missionary activities in Ethiopia from 1555 to 1632". In The missionary factor in Ethiopia. Edited by Getatchew Hayle, Aasuly Lande and Robeson, Samuel. Peter Lang. Frankfurt-an-Main: 31-56.

Moorehead, Alan (1986) El Nilo Azul. Ediciones del Serbal. Barcelona.

Páez, P. (2009) Historia de Etiopía. Vol. I. Edited by Boavida, Isabel, Pennec, Hervé and Ramos, Manuel João. Fundación El Legado Andalusí. Granada.

Páez, P. (2014) Historia de Etiopía. Ediciones del Viento, A Coruña.

Pankhurst, Sylvia (1955) Ethiopia. A cultural history. Lalibela House. Woodford Green.

Pankhurst, Richard (1998) The Ethiopians. A history. Blackwell. Oxford.

Pankhurst, Richard (2000) "Ethiopia's alleged control of the Nile". In The Nile. Histories, Cultures, Myths, edited by Erlich, Haggai and Gershoni. Israel, Lynne-Rienner. Boulder: 25-37.

RASO $=$ Rerum Aethiopicarum Scriptores Occidentales Inediti a saeculo XVI ad XIX, edited by Beccari, Camilo, 15 vols. Excudebat D. de Luigi. Rome: 1903-1917.

Ramos, Manuel João; Boavida, Isabel (editors) (2004) The Indigenous and the Foreign in Christian Ethiopian Art: On Portuguese-Ethiopian Contacts in the 16th and 17th Centuries. Ashgate, London. 
"What the great Alexander and the famous Julius Caesar wanted so much to see". A commemoration of the fourth centenary... 17

Reverte, Javier (2001). Dios, el diablo y la aventura. La historia de Pedro Páez, el español que descubrió el Nilo Azul. Plaza y Janés, Barcelona.

Sáenz-López, Sandra; Pimentel, Juan (2017) Cartografias de lo desconocido. Mapas en la Biblioteca Nacional de España. Biblioteca Nacional de España, Madrid.

Van Donzel, Emery (2000) "The legend of the Blue Nile in Europe". In The Nile. Histories, Cultures, Myths, edited by Erlich, Haggai and Gershoni. Israel, Lynne-Rienner. Boulder: 121-129.

Vijberger, Jacobus; Sibbing, Ferdinand A. and Dejen, Eshete (2009) "Lake Tana: source of the Blue Nile". In The Nile: Origins, Environments, Limnology and Human Use, edited by Dumont, H.S. Springer. New York: 163-192.
Wheeler, Kevin G.; Basheer, Mohammed; Mekonnen, Zelalem T.; Eltoum, Sami O.; Mersha, Azeb; Abdo, Gamal M.; Zagona, Edith A.; Hall, Jim W. and Dadson, Simon J. (2016) "Cooperative filling approaches for the Grand Ethiopian Renaissance Dam". Water International, 41(4): 611-634.

Wright, Jonathan (2005) Los jesuitas. Una historia de los soldados de Dios. Debate. Barcelona.

Yihun Dile, R. Berndtsson, Shimelis Setegn (2013) "Hydrological response to climate change for Gilgel Abbay river, Lake Tana basin - Upper Blue Nile basin of Ethiopia". PLOS ONE 8(10): 379296, October (Open Access publication, licensed to Creative Commons Attribution 2.5 Generic. Wikipedia). 